\author{
Alexander N. Chumakov \\ Finance University under the Government of the Russian Federation, \\ 49, room 105, Leningradsky Prospekt, RU-125993 Moscow \\ chumakov@iph.ras.ru
}

\title{
Philosophy as a Tool of Achieving the Worthy Life
}

\begin{abstract}
Philosophy is seen as an inseparable part of human life and one of the most significant cultural achievements of mankind. It reveals the genuine essence of man in the best way; human being is seen by philosophy as a critical, doubting, questioning, creative being. Main dangers for human beings are now neither economic, nor technological, but those related to their world outlook, where philosophy not simply forms the complex vision of the situation as a whole, but designates specific values and behavioural norms. In the contemporary global world, actively looking for the common platform of intercultural dialogue and ways for sustainable development, philosophy becomes an absolute value itself.
\end{abstract}

\section{Keywords}

philosophy, culture, civilization, values, future, life, man, humankind, paideia

Apart from all values and achievements mankind has acquired throughout the whole history of its existence, philosophy seems to be the most bright and unconditional heritage. Not everyone would agree with this statement, for even among professional philosophers one can find a viewpoint that philosophy has come to its end, is exhausted, and is over (Vattimo, 1991; Swassjan, 2009). Nevertheless, one can positively speak about the unquestionable value of philosophy and, even more, about its growing role under modern circumstances (Habermas, 1988; Hösle, 1990; Syrodeeva, ed., 1997). Without diminishing the meaning of religion and science as well as other values in social life, I would nevertheless position philosophy much higher taking into consideration its role in cultural and civilizational development of both separate peoples and the world community as a whole.

There are several reasons for it. Let me refrain from special consideration of the most important functions of philosophy (world outlook, epistemology, methodology, integration, axiology, communication, etc.) and to start from the main point. Better than any other sphere of human spiritual activity, philosophy reflects our truly human essentiality, characterizing a human being as the one critically thinking, having doubts and, what is principally important - questioning. Below we will dwell on the key role of questioning in philosophy. Now let us emphasize that principal differences between philosophy and other forms of knowledge (religion and science, first of all) can be formulated in various ways. What is important is that religion mostly focuses on answers given ready-made and expected to be taken as they are. Here faith occupies the foreground; it is more important that knowledge. Doubts are not welcome at all; they are seen as more harmful than useful. 
Science is different. It is based on knowledge and oriented towards final and verified answers, which science tries to find relying on previously given knowledge, experience, or intuition. In other words, the task of science is to acquire and increase new knowledge. It is interested, first of all, in correct answers and final results, which can be eventually (or, at least, theoretically) verified or falsified. Knowledge moves here to the foreground, while faith, being present within scientific knowledge, plays, nevertheless, no significant role. Questions are also important for science and doubts are welcome but, finally, they are factored out by theoretically proven and practically tested knowledge, i.e., by ready-made results. In other words, until we have questions and doubts, a scientific result is not final and a scientific research is not considered finished (Global Studies Encyclopedic Dictionary, 2014: 454).

Everything is different in philosophy. Here question, or problem, occupies the central position. Doubt also plays the key role and is highly valued. As for knowledge and faith in philosophy, they play important but supplementary part. Knowledge and faith are only the basis, the fundament of any philosophizing, but they are not its result, which philosophers aspire to reach. Thus, knowledge and faith are only the starting point for philosophical analysis. Their representation is always incomplete, unfinished, and they are dominated by questions and doubts.

Why is this so? It is because philosophy, being basically rational thinking, deals with problems having no unquestionable solutions and not being represented as laws or formulae, answers which cannot be unequivocally proven or finally disproven by practice. They are often called "eternal philosophical problems", meaning that each philosopher and each time provides their own solution for them. Philosophical solutions mostly depend on a philosopher's outlook, things she/he is concerned about, questions she/he asks. Horizons of philosophical issues have no precise boundaries, and the nature of tasks set is defined by many factors. That is why ability to formulate and to ask questions is the central function of philosophy, its essence, source, and driving force of philosophical knowledge (Chumakov, Gay, eds., 2016: 192-211). A philosopher always asks her/his questions to her/himself and, basing on her/his reason, knowledge, experience, intuition, beliefs, convictions, tries to resolve problems of the highest significance for her/himself or for the society with their help.

It follows from the content of the term 'philosophy' that it refers a limitless spectrum of problems and, in fact, transcends the boundaries of available knowledge. We deal here with intellectual games and imagination of specific philosophers and, finally, with their subjective evaluations, positions, and statements. This explains why the path of philosophy is paved by precedents and can never be over, while all talks about "death" or "end of philosophy" are only bravado and épate having nothing to do with reality. At best, one can talk, with some share of conventionality, about the end of this or that philosophical teaching, school, or current because many philosophical ideas, directions, concepts are really over, have no ground in public consciousness, no development or continuation. It is also true that nowadays many of them are in a difficult position or in a deep crisis. But it is not yet philosophy as a whole. Its initial meaning is 'love for wisdom' and as a form of public consciousness, a way of knowledge, as a state of mind, and, finally, as a special type of world outlook, rotates endlessly around uncountable number of problems. Having emerged once, philosophy will accompany homo sapiens until humans remain humans. 
The value and uniqueness of philosophy grows because it is self-sufficient and recognizes, unlike religion and even science, no absolute authorities. For instance, in the case of religion a human being always has some higher authority and criterion of truth (be it God or a sacred text), which she/he inevitably applies to. Science also recognizes unconditional authority of those who have already paved the way of knowledge by their discoveries while practice is a test for the truth of this knowledge. Discovered laws, proven theorems, formulae, theories are indisputable here.

Philosophy has no (and cannot have) such unequivocal authorities and criteria for true philosophical ideas and statements. Philosophy is always in search, it questions everything, rethinking every time what seemed to be already resolved. In a search of philosophical truth a human being, finally, has to count on her/himself only and, as a result, she/he becomes her/his main authority and the basic criterion of truth.

If we define truth as correspondence of our knowledge to reality or as adequate reflection of the objective reality by a subject, only science may deal with such a truth. Philosophy deals not with the truth but with truths of this or that philosopher, i.e. with his subjective certainty that her/his vision of the essence of things is adequate to what goes on in reality. But this does not mean that reality is what this philosopher observes. That is why asking whether she/he is right in her/his judgments and evaluations, one can only answer "may be" and nothing more. This is the principal difference between philosophy and other forms of knowledge. Any philosophical statement, position, or theoretical system, be it maximally substantial and elaborated, cannot have claim to absolute truth and unconditional verification of its prepositions. Other, including directly oppositional, philosophical judgments and concepts still have the right to exist.

This situation is peculiar to philosophy and only to it, making it unique and specially valued social phenomenon. Here rationally oriented human creative activity is able to flourish mostly and in the best way. In addition, philosophy expands horizons of our vision of a problem, having such theoretical, epistemological, ethical, aesthetical, and other opportunities, which, taken together, make it a universal means to achieve our goals in such spheres as morality, law, ethics, aesthetics, international relations, etc.

We would like to stress that philosophical ideas and theories always reflect some objective or subjective reality. They are more valuable the more they lean upon achievements of modern science and on verified knowledge. This point is made also by a Korean philosopher Samuel Lee who, discussing the role of philosophy in the peace studies and movements, states:

\footnotetext{
"Although peace studies should be an interdisciplinary area, it is often claimed to be the task of social science. And many important theories of peace today have been produced by socials scientist, since the analysis of peaceless social international structures and relationship and their interpretation must be investigated scientifically. Philosophers, unless they are trained or equipped to analyse social phenomena scientifically, must hesitate to deal with the problem of war and peace and social or international conflicts." (Lee, 2009: 42-43)
}

So, the value of philosophy, from some viewpoint, seems evident. Nevertheless, we have already mentioned that academic community partly doubts the value and usefulness of philosophy. The following questions are asked: Do we need philosophy now, in the age of high speed and technology? Is it not backward? Is it not replaced with specific knowledge under circumstances of endless informational flow and constant time shortage? Such questions are fully adequate but they are answered by life itself, making modern people 
encounter numerous philosophical problems, of which some are principally new. Here one can probably list prevention of nuclear suicide and keeping peace on the planet, moral and ethical problems of cloning and, what seems even more important - contemporary globalization problems.

The world community faces the third millennium with a new acquired quality. It has become, according to the main parameters of social life, a single holistic system. At the same time, the world community pays more and more attention to the problems of responsibility for the biosphere conditions and continuation of life on Earth. This engenders questions of sustainable socio-economic development and harmonious relations between society and nature, establishing humane, good neighbour relations between separate people and peoples. Such questions, along with eternal philosophical themes, inevitably move to the foreground of modern philosophical studies (Epstein, 1998).

Stoics have mentioned that people try to get rid of philosophy when everything is fine and turn to it when everything goes wrong. This is the time. But is humankind able to recognize it? Will it be able to solve the emerging tasks and to use properly all the available knowledge as well as everything philosophy can give?

We are seriously concerned about the condition and level of development of planetary education, for insufficient education, as well as violation of human rights, seem to be the cause of the majority of modern problems. Protecting human rights becomes task number one because if it is left unresolved, the other tasks become insignificant. One of the experts in the field of human rights İoanna Kuçuradi thinks that

"[...] those who are responsible for the implementation and education of human rights have sufficient philosophical knowledge of the conditions that human rights demand and have become able to put in connection this knowledge with the cases they will face." (Kuçuradi, 2003: 249)

What was mentioned above makes philosophy an unalienable part of human life but, at the same time, an enchanting, mystifying and not acknowledgeable phenomenon. This position is confirmed by the whole history of philosophy demonstrating that none of the peoples, regimes, or ideologies could ignore philosophy, regardless of their attitude to it. And now not only separate peoples, but the world community as a whole ultimately needs philosophy and philosophical vision of itself, its place and mission in life. It is also confirmed by annual worldwide UNESCO Philosophy Days and by the World Congress of Philosophy regularly held since 1900, but now and then returning to the only question of the essence and mission of philosophy.

The 20th World Congress of Philosophy (Boston, 1998) was especially revealing in this regard (The Paideia Archive, 1998). Discussing about its main topic - "Paideia: Philosophy in Human Education" - the world philosophical thought has once again returned to the sources of philosophy and its role in the contemporary global world. Questions that seemed to be resolved long ago were actively discussed: What is philosophy? Who needs it and why? What is its mission and how can it help to confront the global challenges of modernity?

Almost twenty years later we once again ask the same questions. And, once again, we have no single vision of the subject of philosophy, or whether it can purposefully influence social development, and if so, in which way. There are several causes of such variety of positions. The main cause is predetermined by specifics of philosophy itself, which can only exist together with pluralism of opinions, dissent and comparison of various viewpoints. 
It seems a shortage that philosophy does not fit the Procrustean bed of exact and complete knowledge, that it is not a holistic teaching, that it has no single language, common laws, or methodology. But it is, at the same time, its greatest advantage. One can see it clearly dealing with complicated systems and having to resolve complex interdisciplinary problems.

Rethinking such problems from the viewpoint of philosophy has special value. Unlike scientific approaches, philosophical vision of a problem is characterized by more freedom in interpreting facts, by less strict requirements to verification of propositions, by the right to speculative formulae, subjective evaluations, etc. And while, at the first glance, such explorations may seem not so valuable, they actually are.

First, a philosophical study is done in those spheres of rational knowledge where science, restricted by the field of precise knowledge, turns out to be ineffective or even useless. Let us remind that humankind has no other means of rational knowledge but science and philosophy. Second, philosophical reflection widens the horizon of our vision of a problem; it initiates new, unusual approaches to its exploration, including scientific ones. At the same time, science, based on precise formulations and strict proofs cannot afford freedom of evaluation and judgment typical for original philosophical thought.

But how can one domesticate philosophy, use its results in everyday life, how to teach it if it has no precise knowledge and does not even aim at it? And if pluralism, and even completely different answers for a single question, is a philosophical norm, how one can reach monism in her/his head, i.e. ordered, holistic, and relatively coherent worldview?

I would like to mention that for some modern Russian philosophers this problem remains the most complicated one. Marxist philosophy of the Soviet period wanted to be scientific and possessing exact, proven knowledge. It was also taught as such. Those studying philosophy had to learn it as a specific discipline, or as a collection of correct findings. Now, from the position of pluralism in philosophy, recognizing equal value of various philosophical ideas and concepts, such teaching approach becomes a dead end. The question arises: What to teach as philosophy and how? Which ideas and positions should be preferred in the absence of strict criteria of their truth?

This problem is extremely interesting for many international philosophers, as it was demonstrated by the World Congress in Boston. For example, based on the experience of Socrates, Seneca, and the other thinkers of the past, an American philosopher Martha Nussbaum defended in her plenary report a seemingly evident suggestion, which is, nevertheless, not always taken into consideration even now. She said that philosophy should not teach memorizing facts but to develop an ability to reflect and to put questions. The aim of philosophical classes is to teach people to think independently, to follow their own reason and not to turn to authorities in each case. From here the task of philosophy is teaching communication, dialogue, achieving not self-assertion, but search for truth. This means, according to Nussbaum, that all people deserve to be listened to (Confirmed Speakers for Invited Sessions, 1998; "Itogi XX Vsemirnogo filosofskogo kongressa", 1999: 43). These correct and precise words once again confirm that philosophy cannot be learned like a discipline. It cannot be digested as a sum of knowledge, ready-made rules, and formulae. We need a principally new approach. Teaching should choose 
the way of paideia. This means teaching not of "what should be seen", but "where and how to look".

Another plenary speaker at the Congress, a French philosopher Pierre Aubenque also spoke about the educational function of philosophy. He asked: Is it possible to proceed from the barbarian human nature to the civilized one? Aubenque thinks that human nature is dubious and only education (paideia) makes people human in the full sense, or, as Plato used to say, paideia opens our eyes ("Itogi XX Vsemirnogo filosofskogo kongressa", 1999: 43).

But opening eyes is not the purpose of education. Its goal is to provide correct viewpoint. Referring to Plato, Democritus and other prominent thinkers, Aubenque suggests that through education one can make human nature different, direct education against violence, and cultivate human reason. The notion of paideia draws our attention to the educational process, when children become adults. The mechanism of this process can be better understood on the basis of the Antique philosophy stating that divine human nature should be cultivated like good grape. Specifically, Protagoras, Socrates, Plato in their philosophical teaching focused on teaching not so much the art of convincing, but the art of correct judgment. We can find many interesting findings about it in Aristotle's works, who thought that paideia should enforce human self-development ("Itogi XX Vsemirnogo filosofskogo kongressa", 1999: 43).

The Congress and its aftermath have demonstrated that the principle of paideia, where philosophy plays the most important part, had not lost its significance in the modern times and even became more topical. Only a moral human being, physically and spiritually mature, can confront the global challenges of modernity.

Economy or technology as such are not dangerous for humans today, but the very essence of humans themselves. Having started, under objective circumstances, discussing environment, sustainable development, rational usage of nature, they are not yet guided by common concerns and interests of the world community. The world remains divided into "national compartments" where sovereign states continue to guard their independence fiercely, while humankind as a whole gradually becomes, under the influence of globalization, a single social system. Such a system needs adequate - global - governance, still not existing (Chumakov, Grinin, eds., 2015: 30-41). The main cause of such state of affairs is that people have not yet started to think responsibly at the planetary scale, in the categories of the whole humankind. Value systems that emerged in the era of national dissociation do not correspond with the modern situation anymore and should be changed significantly in the short run.

This task can hardly be resolved without philosophy. First of all, it is because we need common and complex vision of the situation as a whole, which can only be provided by philosophy. Philosophy allows observing social life systemically, at large and, at the same time, historically.

It should be emphasized that humanity in its progressive movement reveals two main - but opposite - vectors of development. The first one originates from the formation of primordial people and is defined as the vector of cultural development. The second vector emerges much later and with regard to proceeding to the settled way of life, state building and, finally, civil society formation. It is the vector of civilizational development. They have a lot in common because civilizations emerged as a result of cultural development 
of societies. Moreover, philosophy itself as a form of social consciousness, as a certain type of world outlook and way of knowledge, as the sphere of spirituality and way of life emerges as a result of world cultural and civilizational development. From the period defined by Karl Jaspers as "axial time", philosophy has become an important part of human spiritual life and an unquestionable value.

However, there is a principal difference between culture and civilization (Chumakov, 2015: 75-88). In the system of social relations culture always reveals something specific, private, peculiar about this or that people being rather a distinguishing factor. Being a unifying basis for separate human communities, culture, nevertheless, divides these communities from each other on the basis of language, traditions, beliefs, way of life, folklore, everyday customs, etc. Thus, different peoples become principally divided culturally. Cultural disintegration is objective. It proceeds from cultural diversity fully analogical to the biological one. It seems evident that cultural diversity is a necessary condition for the existence of social life and can be seen as a natural law. This mostly causes differences between people and peoples. All of them are unique because of cultural diversity.

At the same time, we can see that these people reveal common forms of organization of social life. State, with its moral and legal regulators of social relations, is the most bright and elaborated of these forms. These forms characterize civilizational way of development of any society. Thus, civilization emerges as the means of smoothing cultural diversity and uniting people. Civilizational principles of organization of social life are the unifying factor for different countries and peoples.

It is important to mention that having once entered the way of civilizational development a particular social system thus enters the path towards universal global civilization. Different peoples complete this transition differently and with different speed, but the essence of the global civilization does not change: it grows from local and regional civilizational seats. The basic contours of the global civilization have been formed by the end of the 20th century and, together with universal and mass culture, engendered by globalization, they let us speak about the emergence of a single all-human cultural-cum-civilizational system. Two opposite forces act and will always act in this complicated conglomerate of the world community: centrifugal, born by culture, and centripetal, conditioned by civilization. It is not possible to acknowledge this new reality and to build adequate global world outlook without philosophy. This makes philosophy not just a value, but an absolute value. Losing it would mean the loss of human essentiality and the prospect for human worthy future.

That is why, among other values, philosophy should be listed together with such unconditional value as freedom, because it is, in fact, spiritual freedom. At the same time, it is more than freedom, which is an absolutely necessary condition for existence of any philosophy, independent of its teachings, systems, or schools. 


\section{References}

Chumakov, A. N. (2015): Philosophy of Globalization: Selected Articles. 2nd revised and expanded edition. Moscow: Moscow University Press.

Chumakov, A. N.; Grinin, L. E. (eds., 2015): This Globalizing World. Volgograd: "Uchitel” Publishing House.

Chumakov, A. N.; Gay, W. C. (eds., 2016): Between Past Orthodoxies and the Future of Globalization: Contemporary Philosophical Problems. Leiden, Boston: Brill, Rodopi.

Confirmed Speakers for Invited Sessions (1998). http://www.bu.edu/wcp/speakers.html.

Epstein M. (1998): After the Future: The Paradoxes of Postmodernism and Contemporary Russian Culture. Amherst: University of Massachusetts Press.

Global Studies Encyclopedic Dictionary (2014), ed. by A. N. Chumakov, I. I. Mazour, and W. C. Gay, with a foreword by M. Gorbachev. Amsterdam, New York: Rodopi.

Habermas, J. (1988): Nachmetaphysisches Denken: Philosophische Aufsätze. Frankfurt/ M.: Suhrkamp.

Hösle, V. (1990): Die Krise der Gegenwart und die Verantwortung der Philosophie. Munich: C. H. Beck.

“Itogi XX Vsemirnogo filosofskogo kongressa", Voprosy filosofii, No. 5/1999.

Kuçuradi, İ. (2003): "Human Rights, from the Philosophical Point of View", in: Global Studies Encyclopedia, ed. by. A. N. Chumakov, W. C. Gay, and I. I. Mazour. Moscow: Raduga Publishers.

Lee, Samuel (2009): "The Role of Philosophy in the Peace Studies and Movements", in: Papers of the 2007 World Philosophy Day, ed. by İ. Kuçuradi. Ankara: Philosophical Society of Turkey.

Swassjan, K. (2009): Zur Geschichte der Zukunft: Drei Essays. Dornach: Verlag für Anthroposophie.

Syrodeeva, A. A. (ed., 1997): Philosophical Pragmatism of Richard Rorty and the Russian Context. Moscow: Tradition.

The Paideia Archive (1998). http://www.bu.edu/wcp/PaidArch.html.

Vattimo, G. (1991): The End of Modernity: Nihilism and Hermeneutics in Post-modern Culture. Cambridge: Polity Press. 


\title{
Alexander N. Chumakov \\ Filozofija kao sredstvo postizanja vrijednoga života
}

\begin{abstract}
Sažetak
Filozofija se shvaća kao neodvojivi dio ljudskog života i jedno od najznačajnijih kulturnih postignuća ljudskoga roda. Ona raskriva izvornu čovjekovu bit na najbolji način; čovjek se putem filozofije shvaća kao kritičko, sumnjajuće, propitujuće, stvaralačko biće. Glavne opasnosti za ljudska bića sada nisu ni ekonomske, ni tehničke, nego one koje su povezane s njihovim pogledom na svijet, gdje uloga filozofije nije naprosto da oblikuje kompleksnu viziju situacije kao cjeline, nego da određuje specifične vrijednosti i norme ponašanja. U suvremenom globalnom svijetu, aktivno tražeći zajedničke platforme interkulturnog dijaloga i načine održivoga razvoja, filozofija postaje sama apsolutna vrijednost.
\end{abstract}

\section{Ključne riječi}

filozofija, kultura, civilizacija, vrijednosti, budućnost, život, čovjek, ljudski rod, paideia

\section{Alexander N. Chumakov \\ $\underline{\text { Philosophie als Mittel zur Erreichung eines würdigen Lebens }}$}

\begin{abstract}
Zusammenfassung
Die Philosophie wird als ein untrennbarer Teil des menschlichen Lebens und eine der bedeutsamsten kulturellen Errungenschaften der Menschheit angesehen. Sie enthüllt das echte Wesen des Menschen in der besten Weise; anhand der Philosophie wird der Mensch als ein kritisches, zweifelndes, forschendes, kreatives Wesen empfunden. Die Hauptgefahren für die Menschen sind heutzutage weder wirtschaftliche noch technologische, sondern jene, die mit ihrer Weltanschauung zusammenhängen, wo sich die Rolle der Philosophie nicht bloß darauf begrenzt, eine komplexe Vision der Situation als Ganzes zu gestalten, sondern wo sie auch spezifische Werte und Verhaltensnormen aufstellt. In der zeitgenössischen globalen Welt, die aktiv auf der Suche nach einer gemeinsamen Plattform des interkulturellen Dialogs und den Wegen für eine nachhaltige Entwicklung ist, wird die Philosophie zu einem absoluten Wert selbst.
\end{abstract}

\section{Schlüsselwörter}

Philosophie, Kultur, Zivilisation, Werte, Zukunft, Leben, Mensch, Menschheit, Paideia

\section{Alexander N. Chumakov}

\section{La philosophie en tant que moyen pour réaliser une vie vertueuse}

\begin{abstract}
Résumé
La philosophie est considérée comme partie intégrante de la vie humaine et comme l'une des plus importantes réalisations culturelles du genre humain. Elle révèle, de la meilleure des façons, la véritable essence de l'Homme; elle considère l'Homme comme un être critique, doutant, questionnant, créatif. Les dangers qui menacent les êtres humains ne sont à présent ni économiques, ni techniques, mais se rapportent à leur vision du monde, où le rôle de la philosophie ne se réduit pas à former une vision complexe de la situation en tant que tout, mais à établir des valeurs spécifiques et des normes de comportement. Dans le monde globalisé contemporain, la philosophie, à elle-seule, en cherchant de manière active les plates-formes communes du dialogue interculturel et les moyens du développement durable, devient une valeur absolue.
\end{abstract}

\section{Mots-clés}

philosophie, culture, civilisation, valeur, futur, vie, Homme, genre humain, paideia 